\title{
Koulutuksen nopeutettu digiloikka
}

Tänä keväänä kouluissa ja yliopistoissa on eri maissa tehty digiloikkaa vauhdilla, kun koronaviruksen leviämisen estämiseksi lähiopetusta on vähennetty tai oppilaitoksia kokonaan suljettu. Näin myös Venäjällä, jossa maaliskuussa päätettiin sulkea koulut kolmeksi viikoksi, ja myös yliopistoja siirtyi etäopetukseen.

Suomessa etäopetukseen siirtymiseen on ollut korkeakouluissa hyvät valmiudet, onhan esimerkiksi Moodle-alustan käyttö ollut arkipäivää pitkään myös lähiopetuksen yhteydessä. Yliopistojen sulkeutuessa opetus saatiin Suomessa siirrettyä pääosin verkkoon nopeasti, viikossa-kahdessa. Toteutustapoja on erilaisia - ja erilaisia digiopetusalustoja ja opastusta niihin vaikuttaa olevan hyvin tarjolla. Videoneuvottelupalveluiden käyttö opetuksessa nousi kovasti, ja itsekin pidin ensimmäisen suoran verkkoluentoni maaliskuussa.

Venäläisissä korkeakouluissa tehtiin vastaava digiloikka, mutta vaikuttaa siltä että valmiudet ovat vaihdelleet paljonkin. Esimerkiksi Venäjän kansallinen tutkimusyliopisto Higher School of Economics (HSE) on jo vuosia tarjonnut kokonaan verkossa suoritettavia opintoja Coursera-alustalla. Silti HSE:ssäkin tarvittiin digiapulaisiksi informaatioteknologian alan opiskelijoita, kertoo Vedomosti-sanomalehti koosteessaan oppilaitosten tilanteesta. Monissa oppilaitoksissa pidemmälle aikavälille suunniteltu järjestelmien käyttöönotto ja koulutus on nyt tehty pikavauhtia.

Lehden katsaus verkko-opetuksen tilanteeseen kertoo myös eroista yliopistojen välillä. Tomskin teknillisessä yliopistossa (TPU) on jo aiemmin ollut tarjolla 1200 verkkokurssia. Näitä ovat Vedomostiin haastatellun tomskilaisen yliopiston edustajan mukaan opettaneet iäkkäät opettajat, joiden olisi hankala saapua paikalle luentosaleihin. Tšetšenian valtiollisessa pedagogisessa yliopistossa taas käytetään lehden mukaan etäopetukseen ainakin WhatsAppsovellusta, Vkontakte-sivustoa ja Moodle-alustaa, eri opettajilla ja kursseilla on erilaisia käytäntöjä. Moskovan valtionyliopistolla on oma etäopetusalustansa, mutta olen kuullut opettajien järjestelevän etäopiskelua alkuun myös sähköposteilla opiskelijoille.

Tavallisenkin kouluopetuksen avuksi on tullut lisää erilaisia avoimia verkkopalveluita. Esimerkiksi Yandex kehittää Utšebnik (Oppikirja) -alustaansa, jota opettajien on mahdollista käyttää esimerkiksi videolähetyksiin, kotitehtävien antoon ja keskusteluihin oppilaiden kanssa, vastaavaan tapaan kuin Googlen Classroom-palvelu. Yandexin oli huhtikuussa tarkoitus avata vieläpä oma avoin verkossa toimiva koulu, jossa on valmiita oppitunteja ja viihteellisistä sisältöä "välitunneille". Etäkoulu on suunnattu luokille 5-11. Ylimpien luokkien oppilaille on ollut suunnitteilla tämän alustan kautta myös valtakunnallisiin päättökokeisiin valmentavia seminaareja. Nähtäväksi jää, miten paljon venäläiset koululaiset näitä tulevat käyttämään ja mitä muita palveluita vielä kehitetään - ja millaisia keskusteluja ja tutkimusaiheita kouluista, 
koulutuksesta, oppimisesta ja opettamisesta tässä muuttuneessa tilanteessa syntyy, monen muun ajankohtaisen teeman lisäksi.

Tämän Idäntutkimuksen vapaan teeman numeron artikkeleissa Riikkamari Muhonen käsittelee koulutusteemaa erilaisesta näkökulmasta, tarkastellen moskovalaista Kansojen ystävyyden yliopistoa ja sen ideologisen kasvatustyön tuloksia Neuvostoliiton aikana. Kaksi muuta artikkelia sijoittuvat aikahorisontiltaan lähemmäs nykyhetkeä. Marja Sorvarin artikkelissa liikumme kirjallisuuden ylirajaistumisen parissa ja Lotta Ruotsalainen tarkastelee poliittisten repressioiden historiapolitiikkaa Venäjällä.

Hyviä lukuhetkiä.

Helsingissä 29.3.2020

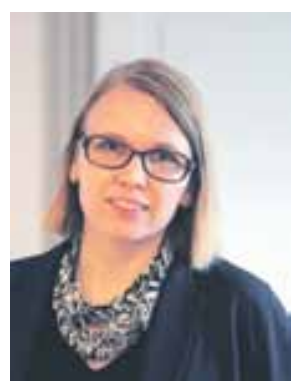

Katja Lehtisari 